Ni Wayan Sudarmini. (2019). Meningkatkan Kemampuan Guru dalam Melaksanakan Proses Pembelajaran Matematika Melalui Penerapan Model Pembelajaran Small Group Work (SGW) dan Supervisi Akademik. Jurnal Penelitian dan Pengembangan Pendidikan. Vol. 3 (3) pp. 249-256.

\title{
Meningkatkan Kemampuan Guru dalam Melaksanakan Proses Pembelajaran Matematika Melalui Penerapan Model Pembelajaran Small Group Work (SGW) dan Supervisi Akademik
}

\author{
Ni Wayan Sudarmini* \\ Pengawas UPT Kecamatan Payangan
}

\begin{abstract}
Abstrak
Penelitian Tindakan Sekolah yang dilakukan ini bertujuan untuk meningkatkan kemampuan guru dalam melaksanakan proses pembelajaran matematika di SD Negeri 2, 3, dan 4 Bukian pada semester I tahun pelajaran 2018/2019. Data hasil penelitian ini dikumpulkan dengan cara melakukan supevisi atau obserpasi kelas/ kunjungan kelas dengan instrumen. Dalam menganalisis data yang diperoleh digunakan metode analisis deskriptif. Data yang dihasilkan dari penelitian ini terdiri dari data awal, data siklus I dan data Siklus II. Dari data awal diperoleh rata-rata kemampuan melaksanakan proses pembelajaran matematika, hanya mencapai nilai 73,76 dan ketuntasan baru mencapai 23,52\%. Data ini jauh di bawah harapan mengingat ketuntasan pelaksanaan proses pembelajaran minimal 80,00. Rata-rata nilai siklus I sudah terjadi peningkatan yaitu rata-ratanya mencapai 77,88 dan prosentase ketuntasannya mencapai 35,29 \%. Pada siklus II perolehan rata-ratanya sudah mencapai 88,94 dan persentase ketuntasan sudah mencapai 100\%. Data pada Siklus II ini sudah sesuai harapan, yaitu kemampuan guru dalam melaksanakan proses pembelajaran matematika di SD Negeri 2, 3, dan 4 Bukian pada semester I tahun pelajaran 2018/2019 mengalami peningkatan melalui penerapan proses pembelajaran mengikuti alur explorasi, elaborasi dan konfirmasi dalam pembelajaran Small Group Work $(S G W)$ dan supervisi akademik.
\end{abstract}

\section{PENDAHULUAN}

Pembelajaran di sekolah akan sangat berarti apabila pengawas mampu memberi rangsanganrangsangan yang membuat guru lebih siap dalam melaksanakan tugas. Untuk mencapai hal ini maka pembelajaran yang disiapkan adalah pembelajaran yang diupayakan dengan metode yang bervariasi dan model-model yang lebih konstruktivis yang mampu merangsang untuk meningkatkan kemampuan serta keterampilan guru yang lebih tinggi.

Pembelajaran di sekolah akan sangat efektif apabila guru melaksanakannya dengan memahami peran, fungsi dan kegunaan mata pelajaran yang diajarnya. Di samping pemahaman akan hal-hal tersebut keefektipan itu juga ditentukan oleh kemampuan guru untuk merubah paradigma pengajaran menjadi pembelajaran.

Beberapa model pembelajaran terbaru harus diupayakan guru demi berhasilnya pengembangan intelektual, sosial dan emosional yang akan berperan sebagai kunci penentu menuju keberhasilan peningkatan hasil belajar. Fungsi mata pelajaran yang diampu perlu untuk dipahami oleh pengawas untuk mempersiapkan guru mampu merefleksikan pengalamannya sendiri, pengalaman orang lain, mengungkapkan gagasan-gagasan dan perasaan serta memahami beragam nuansa makna. Di samping

\footnotetext{
* Corresponding author.
} 
mengetahui peran, fungsi dan kegunaan mata pelajaran yang diampu, sebagai seorang guru juga diperlukan untuk mampu menerapkan beberapa alur dan metode ajar sehingga paradigma pengajaran dapat dirubah menjadi paradigma pembelajaran.

Kelemahan-kelemahan di lapangan selama proses pembelajran yang dilakukan di SD Negeri 2, 3, dan 4 Bukian pada semester I tahun pelajaran 2018/2019 yang menyebabkan rendahnya kemampuan guru dalam melaksanakan proses pembelajaran matematika, tidak sepenunya disebabkan oleh faktor luar seperti kesibukan guru, keadaan rumah tangga, lingkungan dan lain-lain. Kelemahan-kelemahan yang ada banyak pula dipengaruhi oleh faktor dari dalam guru itu sendiri seperti kemauan menyiapkan bahan yang lebih baik, kemauan menyiapkan media-media pembelajaran yang menarik.

Model pembelajaran ini didesain untuk menghidupkan kelas, menciptakan iklim yang menyenangkan dengan mengajak siswa turut serta selama proses pembelajaran baik secara mental maupun fisik (Khasanah, 2012:6). Adapun keuntungan pembelajaran Small Group Work menurut Martinis Yamin dan Bansu I Ansari (2009:72) adalah sebagai berikut. 1) Mendorong siswa untuk mengungkapkan idenya, 2) Melibatkan siswa secara aktif dalam belajar sehingga dapat meningkatkan prestasi siswa, 3) siswa yang mengerti akan menjelaskan kepada temannya, 4) Membantu siswa untuk menghormati siswa lain baik yang pintar maupun lemah dan bekerjasama.

Belajar adalah perubahan tingkah laku yang relatif mantap berkat latihan dan pengalaman (Oemar Hamalik, 2008:154). Sedangkan Good dan Brophy yang dikutip Hamzah B. Uno (2008: 15) mendefinisikan belajar sebagai suatu proses atau interaksi yang dilakukan seseorang untuk memperoleh sesuatu yang baru dalam bentuk perubahan perilaku sebagai hasil dari dari pengalaman itu sendiri. Sehingga dapat disimpulkan bahwa belajar adalah suatu perubahan tingkah laku individu dari hasil pengalaman dan latihan. Minat adalah rasa lebih suka dan rasa keterikatan pada suatu hal atau aktivitas, tanpa ada yang menyuruh (Slameto, 2010:180). Menurut Hilgard yang dikutip oleh Slameto (2010:57) menyatakan “ interest is persisting tendency to pay attention to end enjoy some activity and content". Sardiman A.M (2009:79) berpendapat bahwa minat diartikan sebagai suatu kondisi yang terjadi apabila seseorang melihat ciri-ciri atau situasi yang dihubungkan dengan keinginan-keinginan atau kebutuhannya sendiri.

Adapun faktor yang mempengaruhi minat belajar menurut Aptri Listiyani (2011: 8-9) yakni 1) Faktor dari dalam diri siswa, 2) Faktor dari luar, terdiri dari keluarga, guru, masyarakat dan lingkungan.

Dalam hubungannya dengan pemusatan perhatian, minat mempunyai peranan dalam melahirkan perhatian yang serta merta memudahkan terciptanya pemusatan perhatian, dan mencegah gangguan perhatian dari luar (The Liang Gie, 2004: 57). Dari pengertian belajar dan minat yang telah diuraikan di atas, dapat disimpulkan bahwa minat belajar adalah perubahan tingkah laku individu dari hasil pengalaman dan latihan yang dilakukan dengan penuh ketertarikan dan sungguh-sungguh. Minat belajar memiliki pengaruh yang besar terhadap hasil belajar seseorang.

Nana Sudjana (2005: 3) mendefinisikan hasil belajar sebagai kemampuan-kemampuan yang dimiliki siswa setelah menerima pengalaman belajarnya. Menurut Sugihartono (2007: 114) ciri-ciri belajar yang dapat meningkatkan hasil belajar siswa antara lain sebagai berikut: 1) Menyediakan pengalaman belajar dengan mengkaitkan pengetahuan yang telah dimiliki siswa sedemikian rupa sehingga belajar melalui proses pembentukan pengetahuan, 2) Menyediakan berbagai alternatif pengalaman belajar, tidak semua mengerjakan tugas yang sama, misalnya suatu masalah dapat diselesaikan dengan berbagai cara, 3) Mengintegrasikan belajar dengan situasi yang realistis dan relevan dengan melihatkan pengalaman yang konkrit, misalnya untuk memahami konsep siswa melalui kenyataan kehidupan sehari-hari, 4) Mengintegrasikan pembelajaran sehingga memungkinkan terjadinya transmisi sosial yaitu terjadinya interaksi dan kerjasama seseorang dengan orang lain atau dengan lingkungannya, missal interaksi atau kerjasama antar siswa, guru dan siswa, 5) Menggunakan berbagai metode sesuai dengan kebutuhan siswa, 6) Melibatkan secara emosional dan sosial sehingga siswa menjadi tertarik dan mau belajar, 7) Memanfaatkan berbagai media termasuk komunikasi lisan dan tertulis sehingga pembelajaran menjadi lebih efektif.

Selanjutnya model pembelajaran Small Group Work didefinisikan sebagai model pembelajaran yang menyuruh siswa bekerja sama dalam suatu kelompok daripada menjelaskan secara klasikal (Martinis Yamin dan Bansu I Ansari, 2009:71). Langkah model pembelajaran Small Group work adalah sebagai berikut 1) Membentuk kelompok yang anggotanya 2 atau 3 secara heterogen, 2) Guru menyajikan pelajaran, 3) Guru memberikan tugas kepada tiap kelompok, 4) Guru memberikan kuis/pertanyaan kepada seluruh siswa, 4) Memberikan evaluasi dan kesimpulan.

Semua uraian di atas menunjukkan hal-hal yang perlu dilakukan dalam upaya meningkatkan kemampuan guru melaksanakan proses pembelajaran mengikuti alur Small Group Work (SGW) dan melakukan supervisi akademik. Apabila betul-betul guru menguasai dan mengerti tentang hal-hal tersebut dapat diyakini bahwa kemampuan guru dalam proses pembelajaran bisa ditingkatkan. Namun kenyataannya kemampuan guru dalam melaksanakan proses pembelajaran matematika di SD Negeri 2, 3, 
dan 4 Bukian hanya mencapai rata-rata 73,76 dengan kualifikasi C (cukup). Hal ini sangat jauh dari indikator keberhasilan yang mengharapkan kualifikasi A (amat baik) dengan rentang nilai dari 86-100.

Melihat kesenjangan antara harapan-harapan yang telah disampaikan dengan kenyataan lapangan sangat jauh berbeda, dalam upaya memperbaiki mutu pendidikan sangat perlu kiranya dilakukan perbaikan cara pembelajaran. Salah satunya adalah perbaikan pembelajaran dengan, Supervisi Akademik dengan menggunakan alur pembelajaran Small Group Work (SGW) dan melakukan supervisi akademik Sebagai upaya untuk meningkatkan kemampuan guru dalam melaksanakan proses pembelajaran matematika. Oleh karenanya penelitian ini sangat penting untuk dilaksanakan.

Rumusan masalah dalam penelitian ini terurai sebagai beriku: Apakah penerapan model pembelajaran Small Group Work (SGW) dan supervisi akademik mampu meningkatkan kemampuan guru dalam dalam melaksanakan proses pembelajaran matematika di SD Negeri 2, 3, dan 4 Bukian pada semester I tahun pelajaran 2018/2019? Tujuan penelitian ini adalah Untuk meningkatkan kemampuan guru dalam dalam melaksanakan proses pembelajaran matematika di SD Negeri 2, 3, dan 4 Bukian pada semester I tahun pelajaran 2018/2019 melalui penerapan model pembelajaran Small Group Work (SGW) dan supervisi akademik.

Manfaat hasil penelitian secara teoritis sebagai acuan dalam memperkaya teori dalam rangka peningkatan kompetensi guru. Sedangkan secara praktis penelitian ini diharapkan bermanfaat: 1) bagi siswa, akan mengenal model pembelajaran baru; 2) bagi guru, akan mampu melaksanakan model pembelajaran Small Group Work (SGW); 3) bagi sekolah, sebagai pegangan penanggulangan kwalitas pembelajaran dan 4) bagi pendidik secara umum akan dapat dipakai sebagai pegangan untuk meningkatkan prestasi belajar.

\section{METODE PENELITIAN}

Penelitian yang dilakukan di SD Negeri 2, 3, dan 4 Bukian di harapkan mampu meningkatkan kemampuan gugu-guru dalam pelaksanaan proses pembelajaran. Penelitian tindakan ini terfokus pada penelitian tindakan sekolah. Desain penelitian Tindakan dari ( Depdiknas).

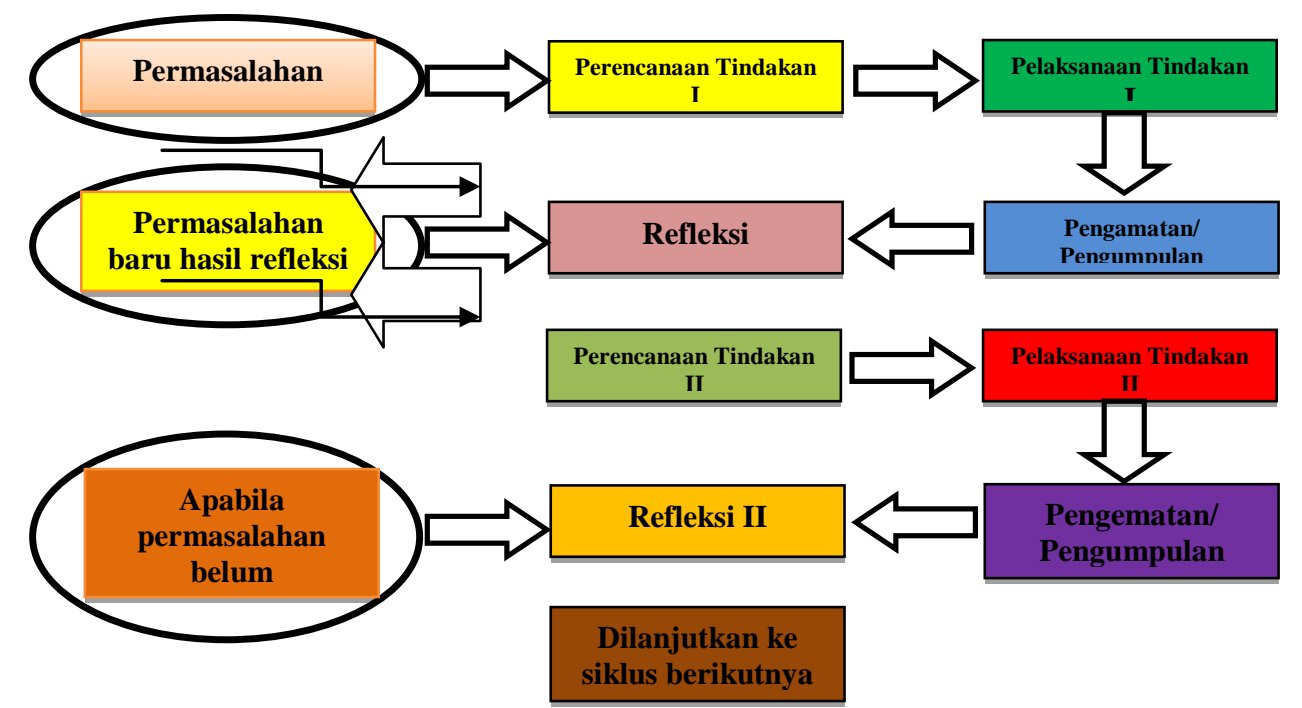

Gambar 1 Alur Penelitian Tindakan kelas Model Suharsimi, (2007)

Perencanaan

Pada tahap ini peneliti membuat RPP, berkonsultasi dengan teman sejawat membuat instrumen. Pada tahap menyusun rancangan diupayakan ada kesepakatan antara guru dan sejawat. Rancangan dilakukan bersama antara peneliti yang akan melakukan tindakan dengan guru lain yang akan mengamati proses jalannya tindakan. Hal tersebut untuk mengurangi unsur subjektivitas pengamat serta mutu kecermatan pengamatan yang dilakukan.

Pelaksanaan Tindakan

Tahap pelaksanaan tindakan dilakukan dengan pembelajaran di kelas.Pada tahap ini guru peneliti giat melakukan tindakan menggunakan model pembelajaran Small Group Work (SGW) dan supervisi akademik. Rancangan tindakan tersebut sebelumnya telah dilatih untuk dapat diterapkan di dalam kelas sesuai dengan skenarionya. Skenario dari tindakan diupayakan dilakspelajaran dengan baik dan wajar. 
Pengamatan atau observasi

Tahap ini sebenarnya berjalan bersamaan dengan saat pelaksanaan. Pengamatan dilakukan pada waktu tindakan sedang berjalan, jadi, keduanya berlangsung dalam waktu yang sama.

Pada tahap ini,guru yang bertindak sebagai peneliti melakukan pengamatan dan mencatat semua hal yang diperlukan dan terjadi selama pelaksanaan tindakan berlangsung. Pengumpulan data ini dilakukan dengan menggunakan tes prestasi belajar yang telah tersusun, termasuk juga pengmatan secara cermat pelaksanaan skenario tindakan dari waktu ke waktu serta dampaknya terhadap proses dan hasil belajar anak.

Refleksi

Tahapan ini dimaksudkan untuk mengkaji secara menyeluruh tindakan yang telah dilakukan, berdasarkan data yang telah terkumpul, kemudian dilakukan evaluasi guna menyempurnakan tindakan berikutnya.

Refleksi dalam PTS mencakup analisis, sintesis, dan penilaian terhadap hasil pengamatan atas tindakan yang dilakukan. Jika terdapat masalah dari proses refleksi maka dilakukan proses pengkajian ulang melalui siklus berikutnya yang meliputi kegiatan: perencanaan ulang, tindakan ulang, dan pengamatan ulang shingga permasalahan dapat teratasi.

Subjek penelitian ini adalah guru-guru SD Negeri 2, 3, dan 4 Bukian dalam pelaksanaan proses pembelajaran semester I tahun pelajaran 2018/2019. Objek Penelitian ini adalah peningkatan kemampuan guru-guru dalam melaksanakan proses pembelajaran matematika dengan menggunakan model pembelajaran Small Group Work (SGW) dan supervisi akademik.

Penelitian tindakan sekolah yang dilakukan ini sudah sudah terjadwal sedemikian rupa yaitu dari bulan Juli sampai bulan Desember pada semester I tahun pelajaran 2018/2019. Kegiatannya termasuk perencanaan/pembuatan proposal pelaksanaan, observasi/pengambilan data dan refleksi.

Metode mengumpulkan data adalah observasi. Observasi adalah suatu teknik atau cara mengumpulkan data dengan jalan mengadakan pengamatan terhadap kegiatan yang sedang berlangsung, kegiatan tersebut bisa memberikan pengarahan, personil bidang kepegawaian yang sedang rapat, dsb (Sukmadinata, 2007: 220). Setelah kegiatan supervisi individual ini berlangsung dilakukan kegiatan supervisi seperti: diksusi, tanya jawab, unjuk kerja dan bersama-sama melakukan studi dokumen terhadap buku-buku pegangan guru. Hasil tanya jawab tidak dipaparkan karena hal tersebut merupakan langkah untuk memperkuat kemampuan guru-guru melaksanakan proses pembelajaran untuk menopang kegiatan nyata yang dilakukan. Unjuk kerja dilakukan dengan melakukan proses pembelajaran setelah mereka siap dengan perencanaan yang telah dibuat. Demikian rencana pengumpulan data yang penulis susun. Adapun data hasil penelitian ini yang dipergunakan dalam menganalisis adalah analisis deskriptif. Untuk menganalisis data hasil penelitian ini digunakan model analisis kuantitatif. Ini dilakukan karena data yang diperoleh berupa angka. Cara analisis yang direncanakan adalah mencari mean, median, modus, , interval kelas, penyajian dalam bentuk tabel dan grafik. Yang penulis rencanakan ini hanya sebatas perhitungan yang gampang pada tingkat statistika dasar.

Instrumen dari penelitian ini adalah lembar observasi yang ada di masing-masing RPP. Indikator keberhasilan dari penelitian ini diusulkan pada siklus I dan siklus II mencapai nilai rata-rata 86 dengan kualifikasi A (Amat baik) yaitu antara 86-100. Dan ketuntasan pembelajaran yang diharapkan mencapai $80 \%$

\section{ANALISIS DAN PEMBAHASAN}

Hasil Penelitian Pada bagian ini pemaparan data nyang diperoleh di lapangan disampaikan secara rinci. Untuk dapatnya menyampaikan sesuatu dengan baik, perlu terlebih dahulu menyimak pendapat para ahli.

Dalam menyampaikan hasil penelitian dan pembahasan, perlu menyajikan uraian masing-masing siklus dengan data lengkap mulai dari perencanaan, pelaksanaan, pengamatan/observasi dan repleksi yang berisi penjelasan tentang aspek keberhasilan dan kelemahan yang terjadi. Perlu ditambahkan hal yang mendasar, yaitu hasil perencanaan (kemajuan) pada diri siswa, lingkungan, guru, motivasi dan aktivitas belajar. Kemukakan grafik dan tabelhasil analisis data yang menunjukkan perubahanyang terjadi disertai pembahasan secara sistimatis danjelads (Suhasimi, Suhardjono, Supardi, 2006:83).

Sesuai pendapat para ahli di atas, maka dalam pemaparan hasil penelitian ini dimulai dengan hasil perencanaan, hasil pelaksanaan, hasil observasi dan hasil refleksi baik yang diperoleh dari kegiatan siklus I maupun kegiatan di siklus II yang didahului dengan deskripsi awal. 


\section{Deskripsi Awal}

Deskripsi yang dapat disampaikan nuntuk perolehan data awal sebagai indikator yang dituntut yaitu minimal guru mampu mencapai ketuntasan belajar dengan nilai sama atau melebihi ketuntasan belum tercapai. Data yang diperoleh menuntukkan hanya 4 guru yang tuntas atau hanya $23,52 \%$ yang tuntas dari 17 guru di SD Negeri 2, 3, dan 4 Bukian pada semester I tahun pelajaran 2018/2019. Data tersebut menunjukkan rendahnya kemampuan guru di SD Negeri 2, 3, dan 4 Bukian dalam melaksanakan proses pembelajaran matematika. Kekurangan yang ada adalah akibat proses pembelajaran yang dilakukan oleh guru masih bersifat konvensional. Kelebihannya adalah peneliti sebagai pengawas telah giat melakukan supervisi secara maksimal.

\section{Deskripsi Siklus I}

Pada siklus I sudah diupayakan untuk perbaikan pembelajaran untuk meningkatkan prestasi dalam melaksanakan proses pembelajaran dengan menggunakan model pembelajaran Small Group Work (SGW) dan dilaksanakannya supervisi akademik selama proses pembelajaran matematika. Peneliti telah giat melakukan kegiatan yang susuai dengan kebenaran teori yang ada sehingga peneliti memperoleh hasil yang lebih baik dari proses awal pembelajaran, yaitu dengan rata-rata nilai 77,88 dari jumlah nilai secara klasikal 1324 dari seluruh guru di SD Negeri 2, 3, dan 4 Bukian, dengan prosentase ketuntasan belajarnya adalah 35,29\%. Kualifikasi nilai yang diperoleh adalah B (baik) yang ada pada rentang 76-85. Hasil ini belum maksimal, karena belum mecapai indikator keberhasilan penelitian yang mencanangkan dengan minimal prosentase ketuntasan belajar $80 \%$.

Deskripsi Siklus II.

Dengan tindakan yang sangat maksimal dan pelaksanaan yang betul-betul mengikuti kebenaran teori sesuai dengan model pembelajaran Small Group Work (SGW) dan dilaksanakannya supervisi akademik dalam melaksanakan proses pembelajaran matematika di SD Negeri 2, 3, dan 4 Bukian, dimana hasil yang diperoleh pada siklus II ini ternyata meningkat secara signifikan dengan nilai rata-rata 88,94 dan ketuntasan belajarnya adalah $100 \%$ dengan kualifikasi nilai yang diperoleh adalah A (amat baik) yang ada pada rentang 86-100.

Pembahasan

Supervisi akademik dengan teknik kunjungan kelas telah diupayakan maksimal. Kendala yang ada adalah pada diri guru yang berlum terbiasa untuk melaksanakan pembelajaran. Mereka masih berpikir bahwa tugas mereka adalah mengajar dan belum betul-betul dimengerti. Kebiasaan ini masih muncul dan mendominasi pembelajaran pada siklus I. Guru pada siklus I ini masih tetap berdiri di depan kelas memperlihatkan diri pada pengawas bahwa mereka adalah mengajar. Hal ini akhirnya dipecahkan dengan kembali berdiskusi dengan guru-guru, bertanya jawab baik pada saat pertemuan awal maupun pada saat dilakukan pertemuan balikan. Peneliti giat melakukan diskusi, memberi pengertian-pengertian pada mereka dalam upaya menstimulir kegiatan yang dilakukan guru demi adanya perbaikan sesuai arti supervisi. Setelah giat dilakukan upaya untuk perbaikan akhirnya pada siklus I ini nilai guru dapat meningkat walaupun belum sesuai harapan dari usulan keberhasilan penelitian. Dari kemampuan guru awal dengan nilai rata-rata 73,76 dengan ketuntasan hanya mencapai $23,52 \%$, akhirnya pada siklus I ini dapat ditingkatkan menjadi rata-rata 77,88 dengan ketuntasan mencapai 35,29\%.

Upaya yang lebih giat yang bisa peneliti laksanakan pada siklus yang kedua ini berpenekanan pada perbaikan-perbaikan dari kekurangan-kekurangan yang ada pada diri guru. Semua kekurangan pada siklus I yang sudah disampaikan pada refleksi siklus I di depan menjadi acuan bagi peneliti untuk melakukan perbaikan. Perbaikan ini banyak dilakukan pada pertemuan awal sebelum mereka masuk kelas. Pada saat bimbingan tersebut diberi penekanan agar mereka merubah cara yang mereka lakukan selama ini yaitu mengajar dirubah dengan membelajarkan. Jadi guru tidak diharapkan untuk menceramahkan materi, guru tidak diharapkan menghabiskan waktunya untuk berdiri di depan kelas dan ngomong a, b, c, dan dan terus menerus mendominasi kelas. Yang dituntut adalah lebih $60 \%$ waktu digunakan oleh siswa untuk memperoleh pengalaman belajar, jadi guru boleh duduk di bangku guru dan tidak harus terus menerus berdiri ngomong ini, ngomong itu sampai habis waktu pembelajaran tetap juga berdiri. Pada pertemuan awal diberikan bimbingan tentang kekurangan-kekurangan yang ada selama siklus I untuk diperbaiki dan diminta agar guru-guru melihat apa yang mereka tulis di RPP dan melaksanakan sesuai apa yang mereka tulis. Disamping itu guru-guru juga diminta untuk memperhatikan waktu sesuai dengan apa yang mereka telah tulis di RPP. Diskusi yang matang yang dilakukan pada pertemuan awal ternyata mampu menghasilkan peningkatan yang cukup signifikan. Dari rata-rata siklus I adalah 77,88 dengan ketuntasan mencapai 35,29\% pada siklus yang ke II naik menjadi 88,94 dengan ketuntasan mencapai $100 \%$. Keberhasilan ini tidak terlepas dari upaya yang sungguh-sungguh, upaya yang maksimal yang dapat ditujukan untuk peningkatan mutu pendidikan.

Rekapitulasi hasil yang dapat disampaikan adalah sebagai berikut. 
Tabel 2. Rekapitulasi Hasil Penelitian

\begin{tabular}{|c|c|c|c|c|c|c|c|c|c|}
\hline \multirow[b]{2}{*}{$\begin{array}{l}\text { No Subyek } \\
\text { Penelitian }\end{array}$} & \multicolumn{3}{|c|}{ Awal } & \multicolumn{3}{|c|}{ Siklus I } & \multicolumn{3}{|c|}{ Siklus II } \\
\hline & $\begin{array}{c}\text { Peroleha } \\
\text { n Skor }\end{array}$ & $\begin{array}{c}\text { Rata- } \\
\text { Rata }\end{array}$ & $\%$ & $\begin{array}{c}\text { Perole- } \\
\text { han Skor }\end{array}$ & $\begin{array}{l}\text { Rata- } \\
\text { Rata }\end{array}$ & $\%$ & $\begin{array}{c}\text { Peroleha } \\
\text { n Skor }\end{array}$ & Rata- Rata & $\%$ \\
\hline 1 & 33 & 66 & $66 \%$ & 38 & 66 & $66 \%$ & 45 & 90 & $90 \%$ \\
\hline 2 & 34 & 68 & $68 \%$ & 39 & 68 & $68 \%$ & 43 & 86 & $86 \%$ \\
\hline 3 & 46 & 92 & $92 \%$ & 46 & 92 & $92 \%$ & 47 & 94 & $94 \%$ \\
\hline 4 & 40 & 80 & $80 \%$ & 41 & 80 & $80 \%$ & 43 & 86 & $86 \%$ \\
\hline 5 & 46 & 92 & $92 \%$ & 46 & 92 & $92 \%$ & 47 & 94 & $94 \%$ \\
\hline 6 & 38 & 76 & $76 \%$ & 40 & 76 & $76 \%$ & 44 & 88 & $88 \%$ \\
\hline 7 & 34 & 68 & $68 \%$ & 36 & 68 & $68 \%$ & 43 & 86 & $86 \%$ \\
\hline 8 & 38 & 76 & $76 \%$ & 39 & 76 & $76 \%$ & 45 & 90 & $90 \%$ \\
\hline 9 & 37 & 74 & $74 \%$ & 40 & 74 & $74 \%$ & 44 & 88 & $88 \%$ \\
\hline 10 & 33 & 66 & $66 \%$ & 35 & 66 & $66 \%$ & 43 & 86 & $86 \%$ \\
\hline 11 & 40 & 80 & $80 \%$ & 40 & 80 & $80 \%$ & 44 & 88 & $88 \%$ \\
\hline 12 & 34 & 68 & $68 \%$ & 38 & 68 & $68 \%$ & 46 & 92 & $92 \%$ \\
\hline 13 & 37 & 74 & $74 \%$ & 38 & 74 & $74 \%$ & 43 & 86 & $86 \%$ \\
\hline 14 & 37 & 74 & $74 \%$ & 37 & 74 & $74 \%$ & 45 & 90 & $90 \%$ \\
\hline 15 & 34 & 68 & $68 \%$ & 35 & 68 & $68 \%$ & 44 & 88 & $88 \%$ \\
\hline 16 & 31 & 62 & $62 \%$ & 35 & 70 & $70 \%$ & 45 & 90 & $90 \%$ \\
\hline Jumlah & 35 & $\begin{array}{c}70 \\
1254\end{array}$ & $70 \%$ & 39 & $\begin{array}{c}78 \\
1324\end{array}$ & $78 \%$ & 45 & $\begin{array}{c}90 \\
1512\end{array}$ & $90 \%$ \\
\hline Rata-rata & & 73,76 & & & 77,88 & & & 88,94 & \\
\hline Ketuntasa & & 23,52 & & & 35,29 & & & $100 \%$ & \\
\hline $\mathrm{n}$ & & $\%$ & & & $\%$ & & & & \\
\hline
\end{tabular}

Penyajian dalam grafik 


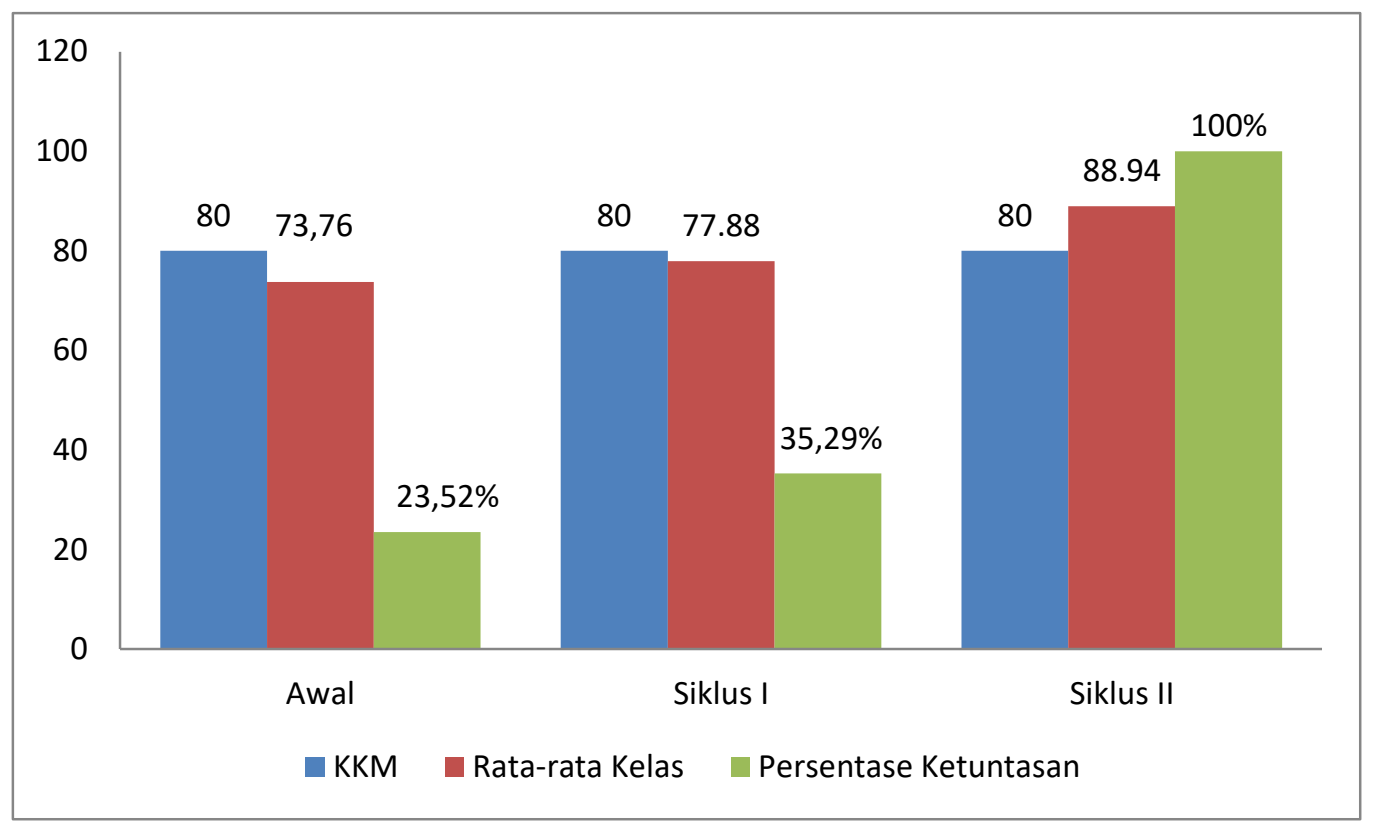

Gambar 2. Rekapitulasi Hasil Penelitian

Hasil penelitian ini sejalan dengan hasil penelitian yang dilakukan oleh Tamrin pada tahun 2017, yang berjudul Pengaruh Penerapan Supervisi Akademik Berbasis Modeling Inspiratif Terhadap Peningkatan Kemampuan Mengajar Guru SD Gugus IV Kecamatan Makassar Kota Makassar. Hasil penelitiannya menunjukkan bahwa ada pengaruh signifikan penerapan supervisi akademik berbasis modeling inspiratif terhdapat peningkatan kemampuan mengajar guru. Hal ini terlihat pada nilai signifikansi lebih kecil daripada $(0,00<0,05)$ yang artinya H1 (artinya ada pengaruh signifikan penerapan supervisi akademik berbasis modeling inspiratif terhadap peningkatan kemampuan mengajar guru SD pada gugus IV Kecamatan Makassar Kota Makassar diterima. Selain itu, respon guru terhdap penerapan supervisi akademik berbasis modeling inspiratif sangat positif.

\section{KESIMPULAN}

Penerapan model pembelajaran Small Group Work (SGW) dan supervisi akademik dapat meningkatkan kemampuan guru di SD Negeri 2, 3, dan 4 Bukian dalam melaksanakan proses pembelajaran matematika pada semester I tahun pelajaran 2018/2019. Ini didukung dengan bukti-bukti dari hasil analisis data kemampuan awal guru masih cukup rendah, bahnyak hal belum mampu dilaksanakan sudah dibenahi. Pada siklus I sudah terjadi peningkatan yang lebih baik dimana banyak unsur yang mesti dilakukan dalam proses pembelajaran sudah dilakukan. Pada akhir siklus II bahkan kemampuan guru-guru sudah cukup baik. Hal-hal yang belum dilakukan dalam pelaksanaan proses pembelajaran sebelumnya sudah dilakukan dan terjadi kenaikan nilai yang diharapkan.

Analisis secara kuantitatif sudah membuktikan bahwa penerapan model pembelajaran Small Group Work (SGW) dan supervisi akademik dapat meningkatkan kemampuan guru di SD Negeri 2, 3, dan 4 Bukian dalam melaksanakan proses pembelajaran matematika pada semester I tahun pelajaran 2018/2019. Perolehan skor awal baru mencapai rata-rata 73,76, membuktikan bahwa kemampuan guruguru dalam melakukan proses pembelajaran masih rendah namun pada akhir siklus I setelah langkahlangkah model pembelajaran Small Group Work (SGW) dan supervisi akademik mulai dilaksanakan, sudah terjadi peningkatan perolehan skor menjadi 77,88, bahkan pada akhir siklus II peningkatannya sudah sangat baik dengan perolehan skor 88,94. Bila dilihat persentase keberhasilannya, pada awalnya baru memperoleh 23,52\%, setelah siklus I mencapai $35,29 \%$ dan pada akhir siklus II telah memperoleh peningkatan yang tajam dengan perolehan yang menggembirakan yaitu $100 \%$ dengan kriteria "Amat Baik". 


\section{DAFTAR PUSTAKA}

Aptri Listiyani. 2011. Upaya meningkatkan minat dan prestasi belajar matematika dengan model pembelajaran kooperatif tipe snowball throwing pada siswa kelas IX SMP Takassus Al-Quran Kalibeber Wonosobo. Skripsi, tidak diterbitkan. Yogyakarta: FKIP UST.

Arikunto Suharsimi, Suhardjono, Supardi. 2006. Penelitian Tindakan. Kelas. Jakarta : Bumi Aksara.

Arikunto, Suharsimi. 2007. Manajemen Penelitian. Jakarta: Rineka Cipta.

Departemen Pendidikan Nasional. 2006. Manajemen Berbasis Sekolah. Jakarta:

Departemen Pendidikan Nasional. 2009. Kompetensi Supervisi Akademik. Jakarta: Dirjen Peningkatan Mutu Pendidik dan Tenaga Kependidikan.

Depdiknas. Departemen Pendidikan Nasional. 2008. Laporan Penelitian Tindakan Sekolah. Jakarta: Depdinas.

Hamalik, Oemar. 2008. Perencanaan Pengajaran Berdasarkan Pendekatan Sistem. Jakarta: Bumi Aksara.

Hamzah B. Uno. 2008. Perencanaan Pembelajaran. Jakarta: Bumi Aksara.

Uswatun Khasanah. 2012. Pengaruh Penerapan Model Active Learning Tipe Small Group Work Pada Pembelajaran Muatan Lokal Membatik Terhadap Hasil Belajar Siswa SMK 1 Pandak. Skripsi, tidak diterbitkan. Yogyakarta: FT. UNY

Slameto, 2010. Belajar \& Faktor-faktor yang Mempengaruhinya. Jakarta: Rineka Cipta.

Sudjana, Nana. 2005. Penilaian Hasil Proses Belajar Mengajar. Bandung: Remaja Rosda Karya

Sukmadinata, Nana Syaodih. 2007. Landasan Psikologi Proses Pendidikan. Bandung: Remaja Rosdakarya.

Tamrin. 2017. Pengaruh Penerapan Supervisi Akademik Berbasis Modeling Inspiratif Terhadap Peningkatan Kemampuan Mengajar Guru SD Gugus IV Kecamatan Makassar Kota Makassar. JIKAP PGSD: Jurnal Ilmiah Ilmu Kependidikan Vol,1. No,2. Tahun 2017 e-ISSN: 2597-4440 dan p-ISSN: 25974424.

The Liang Gie, 2004. Cara Belajar Yang Baik Bagi Mahasiswa. Yogyakarta: Gajah Mada Press. 